\title{
Influence of GA3 and Growing Media on Growth and Seedling Establishment of Papaya (Carica papaya L.) cv. Pusa Nanha
}

\author{
Unmesh Mishra*, Vijay Bahadur, V.M. Prasad, Pushpendra Verty, \\ Ashutosh Kumar Singh, Saket Mishra and N. Swaroop
}

Department of Horticulture, Sam Higginbottom University of Agriculture Technology and

Sciences 211007, (U.P.), India

*Corresponding author

\section{A B S T R A C T}

\section{Keywords}

Papaya, Seedling,

Pusa Nanha, GA,

Growing media.

Article Info

Accepted:

07 September 2017

Available Online:

10 November 2017
An experiment was conducted aimed to find out suitable growth hormone and growing medium for seedling growth of papaya. Experiment was laid out in Factorial completely randomized design with four different levels of $\mathrm{GA}_{3}(0,100,200$, and $300 \mathrm{ppm})$ and seven combinations [Garden Soil, Sand + Garden soil + FYM (1:1:1), Sand + Garden soil + Vermicompost (1:1:1), Sand + Garden soil + Cocopeat (1:1:1), Sand + Garden soil + FYM $(1: 1: 2)$, Sand + Garden soil + Vermicompost (1:1:2) and Sand + Garden soil + Cocopeat $(1: 1: 2)]$ of growing media at main research field, Department of Horticulture, Sam Higginbottom University of Agriculture, Technology and Sciences Allahabad (U.P.) 211007. Findings indicate that treatment $\mathrm{GA}_{3} @ 100$ ppm in $\mathbf{M}_{4}$ (Sand : Garden soil : FYM; 1:1:2) had a significant effect on the vegetative growth, seedling size and its quality, The maximum net return (Rs. 3385.90) was obtained in treatment $\mathrm{G}_{1} \mathrm{M}_{4}\left(\mathrm{GA}_{3} 100 \mathrm{ppm}\right.$ and Sand : Garden soil : FYM; 1:1:2) and maximum benefit cost ratio (5.50) was received treatment in $\mathrm{G}_{0} \mathrm{M}_{4}$ (Control and Sand : Garden soil : FYM; 1:1:2).

\section{Introduction}

The papaya (Carica papaya L.) is an important fruit crop of India and it belongs to genus Carica of the plant family Caricaceae, is grown throughout the tropical and subtropical region of the country.

It is native to the tropics of the Americas, perhaps from southern Mexico and neighboring Central America (Morton, 1987). It was first cultivated in Mexico several centuries before the emergence of the Mesoamerican classical civilizations. Carica papaya $\mathrm{L}$. was the first transgenic fruit tree to have its genome sequenced (Anuburani and
Shakila, 2010). The growers are increasing area under papaya cultivation due to great demand as table fruits as well as vegetable when unripe. It is also used in soft drinks, jams, icecream flavouring etc.

Papaya occupies 2.0 per cent total fruit crop area and 5.3 per cent of total fruit production in India 5120 thousand $\mathrm{mt}$ of production from 124 thousand hectares with average productivity of $42.3 \mathrm{mt} / \mathrm{ha}$ (N.H.B, 2015). The important papaya growing states are Andhra Pradesh, Maharashtra, Gujarat, Karnataka, Madhya Pradesh, Bihar, West Bengal, Tamil 
Nadu, Kerela, Uttar Pradesh and Rajasthan have ideal climate conditions for its growth and production. Papaya is normally propagated by seed (Cheema and Dhani, 1930). A growing medium can be defined as a substance through which plant roots grow and extract water and nutrients. Selecting a good growing medium is fundamental to good nursery management and is the foundation of a healthy root system.

Growing media for use in container nurseries is available in two basic forms: soil based and organic based. Compared with soil based media that has field soil as a major component, organic based media (a base of organic materials that may be compost, peat, coconut coir, or other organic materials, mixed with inorganic ingredients) promotes better root development. In temperate areas, nurseries can choose from a wide range of commercial products for their growing media, including peat moss, vermiculite, and perlite, and premixed blends of these ingredients. Most nurseries in the tropics, however, do not have easy and affordable access to these materials, and even nurseries in temperate areas are seeking to replace some of these ingredients with more local and sustainable materials. In the tropics, growers often create their own media using locally available ingredients (Bharadwaj, 2014).

Gibberelic acid play a vital role in plants specially in fruits crops for example grapes, papaya etc. Cell growth and cell elongation of plants specially in horticultural crops (Bharadwaj, 2014). Gibberelic acid can be used as a seed dormancy breaker. Gibberellic acid is a very potent hormone to trigger germination in fruits seed specially in papaya. Its widely used in the growing industry as a hormone to induce the production of larger bundles and bigger specially Thompson seedless in grapes and papaya (Bharadwaj, 2014)

\section{Materials and Methods}

The experiment was conducted at the Department of Horticulture Research Farm, Sam Higginbottom University of Agriculture \& Technology Sciences, Allahabad during Rabi season 2015-16. The experiment was laid out in poly bags in factorial completely randomized design with three replications. The experiment comprised of twenty eight treatments, Gibberellic acid $\left(\mathrm{GA}_{3}\right)$ presoaking for 12 hours with three concentrations i.e. $\mathrm{GA}_{3}$ at 100ppm $\left(\mathrm{G}_{1}\right)$, 200ppm $\left(\mathrm{G}_{2}\right)$, 300ppm $\left(G_{3}\right)$ and Control as water soaking of seeds $\left(\mathrm{G}_{0}\right)$ and different growing media used in different ratio i.e. Garden soil as control $\left(\mathrm{M}_{0}\right)$, Sand + Garden soil + FYM (1:1:1) $\left(\mathrm{M}_{1}\right)$, Sand + Garden soil + Vermicompost (1:1:1) $\left(\mathrm{M}_{2}\right)$, Sand + Garden soil + Cocopeat (1:1:1) $\left(\mathrm{M}_{3}\right)$, Sand + Garden soil + FYM (1:1:2) $\left(\mathrm{M}_{4}\right)$, Sand + Garden soil + Vermicompost (1:1:2) $\left(\mathrm{M}_{5}\right)$ and Sand + Garden soil + Cocopeat (1:1:2) $\left(\mathrm{M}_{6}\right)$. The germination percentage was worked out after complete germination of the seeds. It was calculated by dividing the total number of seeds sown by the number of seeds germinated and was multiplied by 100 . Observations were recorded with respect to seedling height, number of leaves and stem girth at 120 days after sowing (DAS). Seedling height was measured from base of seedling to highest tip of plant. Stem diameter was measured $1 \mathrm{~cm}$ above from the base of the stem using Vernier Caliper. Length of taproot was measured by destructive method of uprooting the plant and taking measurement by standard method. Seedling vigour was calculated using the formula:

Vigour index $=$ Percent germination $\times$ Length of seedling (Bewley and Black, 1982).

Survival per cent was recorded by using following formula; Survival $\%=$ Total survived seedlings/Total germinated seeds $\times$ 100 
All data were subjected to analysis of variance (ANOVA) to determine significant differences and comparison of mean at a significant level of $5 \%$.

\section{Results and Discussion}

\section{Effect of $\mathrm{GA}_{3}$ on seedling growth and survival percentage}

The results (Table 1) revealed that the maximum $(66.9 \%)$ seed germination of papaya was obtained under $\mathrm{G}_{1}$ (100 ppm $\left.\mathrm{GA}_{3}\right)$ followed by $\mathrm{G}_{3}(63.86 \%)$ and $\mathrm{G}_{2}$ $(61.62 \%)$. The promising effect of $\mathrm{GA}_{3}$ as pre-sowing treatment to the seeds replaced the dormancy mechanism of the seeds resulting in early germination (Khan, 1981). The maximum seed germination period (11.09) of papaya was obtained under in control followed by $\mathrm{G}_{3}\left(300\right.$ ppm $\left.\mathrm{GA}_{3}\right)$ (7.97) and $\mathrm{G}_{1}$ (6.37). The minimum germination period (5.42) was recorded in $\mathrm{G}_{2}$. The maximum seed germination index (1.82) of papaya was obtained under $\mathrm{G}_{1}\left(100\right.$ ppm $\left.\mathrm{GA}_{3}\right)$ followed by $\mathrm{G}_{3}$ (1.73) and $\mathrm{G}_{2}$ (1.68). The maximum seedling vigour index (6159.77) of papaya was obtained under $\mathrm{G}_{2}\left(200 \mathrm{ppm} \mathrm{GA}_{3}\right)$ followed by $G_{1}$ (5498.13) and $G_{0}$ (5326.99). Gibberellic acid acts on the embryo and causes synthesis of hydrolyzing enzymes particularly growth of embryo and this hydrolyzed food is utilized for growth of embryo and there by enhanced the germination (Paleg, 1965). Similar finding were reported by \{Dhankar and Singh (1996) in aonla; Bharche et al., (2010), Dhinesh Babu et al., (2010) in papaya .

The various vegetative growth parameters such as height of the seedling, number of leaves per seedling, stem girth and length of tap root were found to be significant among different treatments (Table 1). At 120 days after sowing (DAS) the seeds pre-treated with $\mathrm{GA}_{3} 200 \mathrm{ppm}$ recorded maximum height of the seedling $(24.62 \mathrm{~cm})$ followed by $\mathrm{GA}_{3} 100$ ppm $(24.00 \mathrm{~cm})$ and $300 \mathrm{ppm}(23.69 \mathrm{~cm})$. The increased height in $\mathrm{GA}_{3} 200 \mathrm{ppm}$ seeds may be attributed to the reason that the endogenous levels of $\mathrm{GA}_{3}$ synthesized by the papaya seedling might not be sufficient and external application of $\mathrm{GA}_{3}$ might have boosted growth by increasing cell multiplication and cell elongation resulting in better plant growth. The results obtained in the present investigation are in close conformity with the results obtained by Pawshe et al., (1997).

The number of leaves per seedling was maximum with $\mathrm{GA}_{3} 300$ ppm (14.91) followed by $\mathrm{GA}_{3} 100 \mathrm{ppm}$ (14.57) and 200 ppm (14.22) whereas, control recorded the minimum (12.75) at 120 days of sowing respectively (Table 1). Increase in number of leaves might be due to the reason that $\mathrm{GA}_{3}$ helps in invigoration of physiological process of plant and stimulatory effect of chemicals to form new leaves at a faster rate. The results are in conformity of Sen et al., (1990) in papaya seeds.

The stem girth recorded at 120 days after sowing was significantly maximum in seeds presoaking in $\mathrm{GA}_{3} 100 \mathrm{ppm}(9.23 \mathrm{~mm})$ followed by $\mathrm{GA}_{3} 300 \mathrm{ppm}(8.86 \mathrm{~mm})$ and 200 ppm $(8.63 \mathrm{~mm})$ whereas, control recorded the minimum $(8.56 \mathrm{~mm})$. The increase in diameter as a result of $\mathrm{GA}_{3}$ application might be due to the fact that $\mathrm{GA}_{3}$ increase somatic uptake of nutrients causing cell elongation and thus increasing height of the plant (Faucht and Watson, 1958). Similar, results were also recorded by Dhankar and Singh (1996) in aonla and Bharche et al., (2010) in papaya. The maximum length $(27.70 \mathrm{~cm})$ of tap root recorded at 120 days after sowing was recorded with seed soaking in $\mathrm{GA}_{3} 100 \mathrm{ppm}$ (Table 1) followed by $\mathrm{GA}_{3} 200$ ppm (27.25 $\mathrm{cm})$ and $300 \mathrm{ppm}(26.26 \mathrm{~cm})$ whereas, control recorded the minimum $(25.91 \mathrm{~cm})$. 
Table.1 Effect of $\mathrm{GA}_{3}$ and Growing media on germination percentage, germination period, germination index, vigour, seedling height, number of leaves, stem girth, root parameter and survival percentage in papaya

\begin{tabular}{|c|c|c|c|c|c|c|c|c|c|}
\hline Treatments & $\begin{array}{l}\text { Germination } \\
\text { percentage }\end{array}$ & $\begin{array}{l}\text { Germination } \\
\text { period }\end{array}$ & $\begin{array}{l}\text { Germination } \\
\text { index }\end{array}$ & $\begin{array}{l}\text { Vigour } \\
\text { index }\end{array}$ & $\begin{array}{l}\text { Seedling } \\
\text { height } \\
(\mathrm{cm}) 120 \\
\text { DAS }\end{array}$ & $\begin{array}{l}\text { Number } \\
\text { of leaves }\end{array}$ & $\begin{array}{l}\begin{array}{l}\text { Stem } \\
\text { girth } \\
(\mathrm{mm})\end{array} \\
120 \text { DAS }\end{array}$ & $\begin{array}{l}\text { Length of } \\
\text { tap root } \\
(\mathrm{cm}) 120 \\
\text { DAS }\end{array}$ & $\begin{array}{l}\text { Survival } \\
\text { percentage }\end{array}$ \\
\hline G0 & 58.26 & 11.09 & 1.43 & 5326.99 & 23.342 & 12.75 & 8.56 & 25.92 & 56.16 \\
\hline G1 & 66.9 & 6.37 & 1.82 & 5498.13 & 24.004 & 14.57 & 9.24 & 27.71 & 65.02 \\
\hline G2 & 61.62 & 5.43 & 1.68 & 6159.77 & 24.622 & 14.23 & 8.64 & 27.25 & 59.74 \\
\hline G3 & 63.86 & 7.97 & 1.73 & 4305.86 & 23.699 & 14.91 & 8.86 & 26.26 & 63.05 \\
\hline $\mathrm{SE}(\mathrm{d})$ & 0.23 & 0.38 & 0.02 & 7.97 & 0.73 & 0.11 & 0.06 & 0.09 & 0.38 \\
\hline C.D. & 0.46 & 0.78 & 0.04 & 16.32 & 2.45 & 0.22 & 0.11 & 0.19 & 0.78 \\
\hline M0 & 56.51 & 8.53 & 1.49 & 4738.16 & 23.72 & 13.42 & 8.53 & 26.2 & 54.26 \\
\hline M1 & 69.73 & 8.33 & 1.96 & 5732.94 & 22.21 & 13.35 & 8.44 & 26.64 & 67.87 \\
\hline M2 & 65.56 & 7.22 & 1.69 & 4709.13 & 23.89 & 14 & 9.13 & 26.5 & 63.67 \\
\hline M3 & 54.61 & 7.48 & 1.4 & 5129.58 & 23.87 & 13.93 & 8.63 & 26.49 & 52.73 \\
\hline M4 & 73.53 & 7.6 & 1.76 & 5426.44 & 25.21 & 15.57 & 8.99 & 27.9 & 72.59 \\
\hline M5 & 65.6 & 7.43 & 1.73 & 5472.69 & 24.36 & 14.32 & 8.87 & 26.99 & 64.65 \\
\hline M6 & 53.05 & 7.42 & 1.63 & 6049.9 & 24.14 & 14.23 & 9.17 & 26.76 & 51.16 \\
\hline $\mathrm{SE}(\mathrm{d})$ & 0.31 & 0.29 & 0.01 & 6.027 & 0.73 & 0.15 & 0.07 & 0.12 & 0.286 \\
\hline C.D. & 0.62 & 0.59 & 0.03 & 12.34 & 2.45 & 0.29 & 0.15 & 0.25 & 0.586 \\
\hline G0M0 & 52.33 & 11.4 & 0.79 & 3094.12 & 23.32 & 11.6 & 8.37 & 25.75 & 49 \\
\hline G0M1 & 55.13 & 11.33 & 1.5 & 4033.08 & 24.29 & 12.13 & 8.31 & 26.89 & 53.25 \\
\hline G0M2 & 59.53 & 11.53 & 1.18 & 4475.65 & 23.71 & 12.73 & 8.38 & 26.31 & 57.64 \\
\hline G0M3 & 56.33 & 10.47 & 1.14 & 5908.03 & 22.85 & 12.6 & 8.66 & 25.45 & 54.44 \\
\hline G0M4 & 63.26 & 10.73 & 1.56 & 5977.03 & 22.4 & 13.53 & 8.28 & 25 & 61.38 \\
\hline G0M5 & 61.26 & 10.8 & 1.95 & 6844.14 & 23.09 & 13.47 & 8.767 & 25.69 & 59.38 \\
\hline G0M6 & 59.93 & 11.4 & 1.92 & 6956.91 & 23.73 & 13.2 & 9.16 & 26.33 & 58.04 \\
\hline G1M0 & 62.8 & 6.87 & 1.74 & 7459.02 & 23.96 & 14.27 & 8.367 & 26.54 & 60.91 \\
\hline G1M1 & 76 & 6.73 & 2.85 & 8574.9 & 16.75 & 13.47 & 8.853 & 26.69 & 74.23 \\
\hline G1M2 & 72.8 & 6.27 & 1.97 & 3925.18 & 23.87 & 13.73 & 12.253 & 26.47 & 70.91 \\
\hline G1M3 & 59.86 & 6.47 & 1.42 & 4525.98 & 24.97 & 14 & 9.093 & 27.63 & 57.98 \\
\hline G1M4 & 77.53 & 6.67 & 1.45 & 4510.44 & 28.33 & 16.73 & 8.313 & 31.13 & 75.64 \\
\hline G1M5 & 71.33 & 6.33 & 1.89 & 4639.1 & 25.45 & 14.8 & 9.03 & 28.15 & 69.44 \\
\hline G1M6 & 47.93 & 5.27 & 1.45 & 4852.28 & 24.69 & 15 & 8.76 & 27.33 & 46.04 \\
\hline G2M0 & 50.13 & 7.2 & 1.74 & 5305.17 & 24.17 & 13.6 & 8.43 & 26.77 & 48.24 \\
\hline G2M1 & 74.53 & 7.13 & 1.83 & 5787.59 & 23.55 & 14.13 & 8.26 & 26.12 & 72.64 \\
\hline G2M2 & 67.8 & 3.8 & 1.93 & 5915.06 & 24.44 & 13.8 & 7.49 & 27.06 & 65.91 \\
\hline G2M3 & 47.26 & 5.8 & 1.41 & 5435.01 & 24.3 & 13.67 & 7.49 & 26.9 & 45.38 \\
\hline G2M4 & 77.26 & 5.47 & 1.97 & 6355.83 & 26.74 & 16.87 & 10.17 & 29.51 & 75.38 \\
\hline G2M5 & 65.13 & 3.93 & 1.43 & 6425.15 & 24.57 & 13.6 & 9.25 & 27.19 & 63.24 \\
\hline G2M6 & 49.26 & 4.67 & 1.48 & 7894.59 & 24.58 & 13.93 & 9.37 & 27.21 & 47.38 \\
\hline G3M0 & 60.8 & 8.67 & 1.71 & 3094.31 & 23.43 & 14.2 & 8.97 & 25.76 & 58.91 \\
\hline G3M1 & 73.26 & 8.13 & 1.67 & 4536.17 & 24.26 & 13.67 & 8.33 & 26.86 & 71.38 \\
\hline G3M2 & 62.13 & 7.27 & 1.69 & 4520.63 & 23.56 & 15.73 & 8.4 & 26.16 & 60.24 \\
\hline G3M3 & 55 & 7.2 & 1.64 & 4649.29 & 23.35 & 15.47 & 9.29 & 25.96 & 53.11 \\
\hline G3M4 & 76.06 & 7.53 & 2.08 & 4862.47 & 23.37 & 15.13 & 9.23 & 25.97 & 77.96 \\
\hline G3M5 & 64.66 & 8.68 & 1.64 & 3982.37 & 24.35 & 15.4 & 8.43 & 26.95 & 66.56 \\
\hline G3M6 & 55.06 & 8.33 & 1.69 & 4495.8 & 23.58 & 14.8 & 9.39 & 26.18 & 53.18 \\
\hline SE(d) & 0.61 & 0.76 & 0.04 & 15.94 & 1.93 & 0.29 & 0.15 & 0.25 & 0.76 \\
\hline C.D. & 1.24 & 1.55 & 0.08 & 32.65 & 3.88 & 0.59 & 0.3 & 0.49 & 1.55 \\
\hline
\end{tabular}


This might be due to the fact that, $\mathrm{GA}_{3}$ increases somatic uptake of nutrients, causing cell elongation and thus increasing the length of tap root and number of secondary roots. The results obtained in the present studies are in agreement with that reported by Wagh et al., (1998) in aonla. Maximum survival $(65.02 \%)$ was noticed in seed treatment with $\mathrm{GA}_{3} 100$ ppm followed by 300 ppm (63.04) and 200 ppm $(59,73)$. The minimum survival percentage (56.16) was recorded in control.

\section{Effect of growing media on seedling growth and survival percentage}

Among different media significantly maximum germination percentage of papaya seeds $(73.53 \%)$ were recorded in $\mathrm{M}_{4}$ media i.e. Sand + Garden soil + FYM (1:1:2) followed by $\mathrm{M}_{1}$ (Sand + Garden soil + FYM; 1:1:1) $(69.73 \%)$ and $\mathrm{M}_{5}$ (Sand + Garden soil + Vermicompost; 1:1:1) (65.6 \%) media. Treatments $\mathrm{M}_{4}, \mathrm{M}_{1}$ and $\mathrm{M}_{5}$ show at par value. It might due to the reason that media containing organic manures possess organic acid within them. Therefore, more available moisture and some acids may have helped in minimum days to germination and better germination percentage. Similar results were reported by Prasana et al., (2014) in mango.

Among different media significantly maximum germination period of papaya seeds (8.53) were recorded in $\mathrm{M}_{0}$ media i.e. (Garden soil; 1 ) followed by $\mathrm{M}_{1}$ (Sand + Garden soil + FYM; 1:1:1) (8.33) and $\mathrm{M}_{4}$ (Sand + Garden soil + FYM; 1:1:2) (7.60) media. The minimum germination period (7.21) was recorded in $\mathrm{M}_{2}$ (Sand + Garden soil + Vermicompost; 1:1:1). Treatments $\mathbf{M}_{0}, \mathbf{M}_{1}$, $\mathrm{M}_{4}$ and $\mathrm{M}_{2}$ show at par value. The maximum germination index of papaya seeds (1.96) were recorded in $\mathrm{M}_{1}$ i.e. (Sand + Garden soil + FYM; 1:1:1) followed by $\mathrm{M}_{4}$ (Sand + Garden soil + FYM; 1:1:2) (1.76) and $\mathrm{M}_{5}$ (Sand + Garden soil + Vermicompost; 1:1:2)
(1.72) media. Treatments $\mathrm{M}_{1}, \mathrm{M}_{4}$ and $\mathrm{M}_{5}$ show at par value. Growing media also plays important role for seed germination. Growing medium not only acts as a growing place but also as a source of nutrient for plant growth. Media composition used influences the quality of seedling Wilson et al., (2001). Humic acids (vermicompost) applied in the medium increased plant height, leaf area and dry weight of peppers, tomatoes and marigold Arancon et al., (2004).

The maximum height of seedling $(25.21 \mathrm{~cm})$ at 120 DAS was recorded in $\mathrm{M}_{4}$ (Sand + Garden soil + FYM; 1:1:2) media followed by $\mathrm{M}_{5}$ (Sand + Garden soil + Vermicompost; 1:1:2) media $\left(24.36 \mathrm{~cm}\right.$ ) and $\mathrm{M}_{6}$ (Sand + Garden soil + Cocopeat; 1:1:2) media (24.14 $\mathrm{cm})$. This may be attributed to general improvement in the physical and chemical properties of the rooting medium. Similar results were obtained by Shamet et al., (1994) in Chilgoza pine, and Nelson et al., (2008) in arnotta plant (Bixa orellana).

Similarly at 120 DAS also $\mathrm{M}_{4}$ i.e. (Sand + Garden soil + FYM; 1:1:2) media produced maximum number of leaves per plant (15.56) closely followed by $\mathrm{M}_{5}$ i.e. (Sand + Garden soil + Vermicompost; 1:1:2) media (14.31) and $\mathrm{M}_{6}$ i.e. (Sand + Garden soil + Cocopeat; $1: 1: 2$ ) media (14.23) number of leaves respectively. In respect of stem girth at 120 DAS M $\mathrm{M}_{6}$ i.e. (Sand + Garden soil + Cocopeat; 1:1:2) media produced maximum stem girth $9.17 \mathrm{~mm}$ respectively at 120 DAS which was followed by $\mathrm{M}_{5}$ i.e. (Sand + Garden soil + Vermicompost; 1:1:2) media $9.13 \mathrm{~mm}$ and $\mathrm{M}_{4}$ i.e. (Sand + Garden soil + FYM; 1:1:2) media $8.99 \mathrm{~mm}$ respectively. It may be due to better nutrient availability leading to higher production of photo synthetically functional leaves due to growing media (Borah et al., 2008). Similar results were reported by Anjanawe et al., (2013) in papaya and Parasana et al., (2014) in mango. 
The length of tap root was significantly maximum $(27.90 \mathrm{~cm})$ in media treatment $\mathrm{M}_{4}$ i.e. (Sand + Garden soil + FYM; 1:1:2) followed by $\mathrm{M}_{5}$ i.e. (Sand + Garden soil + Vermicompost; 1:1:2) (26.99 $\mathrm{cm})$ and $\mathrm{M}_{6}$ i.e. (Sand + Garden soil + Cocopeat; 1:1:2) $(26.76 \mathrm{~cm})$ whereas, the minimum length of tap root $(26.20 \mathrm{~cm})$ were reported in control. This could be due to availability of sufficient nutrient content in Farmyard Manure. Farm yard Manure initially forms conductive environment with regard to physical parameters of soil which promotes better root growth.

Vermicompost represented hormone-like activity and increased the number of roots, thereby, enhancing nutrient uptake as well as plant growth and development (Alvarez and Grigera, 2005). Similar results were obtained by Yadav et al., (2012) in acid lime using soil: sand: vermicompost: vermiculite: cocopeat $(1: 1: 1: 1: 1)$ media.

Among different media significantly maximum seedling vigor index (6049.9) of papaya seeds were recorded in $\mathrm{M}_{6}$ i.e. (Sand + Garden soil + Cocopeat; 1:1:2) followed by $\mathrm{M}_{1}$ (Sand + Garden soil + FYM; 1:1:1) (5732.94) and $\mathrm{M}_{5}$ (Sand + Garden soil + Vermicompost; 1:1:2) (5472.69) media. Treatments $\mathrm{M}_{6}, \mathrm{M}_{1}$ and $\mathrm{M}_{5}$ show at par value. This might be due to the fact that this media has suitable physical properties Ramteke et al., (2015).

The maximum survival i.e. $72.59 \%$ was recorded in $\mathrm{M}_{4}$ (Sand + Garden soil + FYM; 1:1:2) media, while minimum survival (51.16 $\%$ ) was observed in the media $\mathrm{M}_{6}$ i.e. (Sand + Garden soil + Cocopeat; 1:1:2). This may be due to favorable media for better growth of the seedling, particularly for good development of a root system. These results are in close agreement with Shamet et al., (1994).
Interaction effect of $\mathrm{GA}_{3}$ and growing media on seedling growth and survival percentage

Interaction of $\mathrm{G}_{1} \mathrm{M}_{4}\left\{\mathrm{GA}_{3} 100 \mathrm{ppm}\right.$ and (Sand + Garden soil + FYM; 1:1:2)\} recorded maximum germination percentage of papaya seeds $(77.53 \%)$. Interaction of $\mathrm{G}_{2} \mathrm{M}_{2}\left\{\mathrm{GA}_{3}\right.$ $200 \mathrm{ppm}$ and (Sand + Garden soil + Vermicompost; 1:1:1)\} recorded minimum germination period of papaya seeds (3.8). Interaction of $\mathrm{G}_{1} \mathrm{M}_{1}\left\{\mathrm{GA}_{3} 100 \mathrm{ppm}\right.$ and (Sand + Garden soil + FYM; 1:1:1)\} recorded maximum germination index of papaya seeds (2.85). Maximum height of seedling (28.33 $\mathrm{cm})$ was reported in $\mathrm{G}_{1} \mathrm{M}_{4}\left\{\mathrm{GA}_{3} 100 \mathrm{ppm}\right.$ and (Sand + Garden soil + FYM; 1:1:2) \} whereas, maximum number of leaves (16.86) was reported in $\mathrm{G}_{2} \mathrm{M}_{4}\left\{\mathrm{GA}_{3} 200 \mathrm{ppm}\right.$ and (Sand + Garden soil + FYM; 1:1:2)\}, Stem girth $(12.25 \mathrm{~mm})$ was observed in the treatment combination $\mathrm{G}_{1} \mathrm{M}_{2}\left\{\mathrm{GA}_{3} 100 \mathrm{ppm}\right.$ and (Sand + Garden soil + Vermicompost; 1:1:1) $\}$ and maximum length of tap root $(31.13 \mathrm{~cm})$ was reported in $\mathrm{G}_{1} \mathrm{M}_{4}\left\{\mathrm{GA}_{3} 100 \mathrm{ppm}\right.$ and (Sand + Garden soil + FYM; 1:1:2)\} at 120 DAS. Maximum vigor index (8574.9) was noticed in $\mathrm{G}_{1} \mathrm{M}_{1}\left\{\mathrm{GA}_{3} 100 \mathrm{ppm}\right.$ and (Sand + Garden soil + FYM; 1:1:1)\} whereas, maximum survival percentage (77.96) was noticed in $\mathrm{G}_{3} \mathrm{M}_{4}\left\{\mathrm{GA}_{3} 300 \mathrm{ppm}\right.$ and (Sand + Garden soil + FYM; 1:1:2)\}. The promising effect of GA3 on seed germination might be due to its participation in the activity of alpha amylase, which catalyzes the starch conversion into simple carbohydrates and chemical energy is liberated which is used in the activation of embryo (Anjanawe et al., 2013). Growth media has appropriate cation exchange capacity for retention of nutrients and having properties like good water holding capacity as well as sufficient porosity, thus permitting adequate moisture and exchange of gasses between the germination growth media and the embryo. It is essential for rapid and 
uniform germination of seeds (Anjanawe et al., 2013).

\section{References}

Alvarez, R. and Grigera, S. (2005). Analysis of soil fertility and management effects on yields of wheat and corn in the rolling Pampa of Argentina. Journal of Agronomy and Crop Sciences 191: 321329.

Anburani, A. and Shakila, A. (2010). Influence of seed treatment on the enhancement of germination and seedling vigour of papaya. Acta Horticulture 851: 295-298.

Anjanawe, S. R., Kanpure, R. N., Kachouli, B. K. and Mandloi, D. S. (2013). Effect of plant growth regulators and growth media on seed germination and growth vigour of papaya. Annals of Plant and Soil Research. 15(1): 31-34.

Arancon N.Q. Lee S., Edwards C.A., and Atiyeh R. (2004). Effect of humic acids derived from cattle, food and paper waste vermicompost on growth of green house plants. Pedobiologia 47: 741 744.

Bewley, J. D. and Black, B. M. (1982). Germination of seeds. In: Physiology and Biochemistry of Seed Germination. Ed: Khan, A.A., Springer Verlag, New York, pp. 40-80.

Bharadwaj R.L. (2014). Effect of growing media on seed germination and seedling growth of papaya cv. 'Red lady'. African Journals of Plant Sciences, Vol 8(4), pp. $178-184$.

Bharche, S. K., Singh, K. and Singh, D. B. (2010). Response of seed treatment on germination, growth, survivability and economics of different cultivars of papaya (Carica papaya L.). Acta Horticulture 851: 279 - 281.

Borah, A. S., Nath, A., Ray, A. K., Bhat, R., Maheswarappa, H. P., Subramanian, P.,
Dileep, M., Sudhakara, K., Santhoshkumar, A. V., Nazeema, K. K. and Ashokan, P. K. (1994). Effect of seed size, rooting medium and fertilizers on the growth of seedlings of silk cotton (Ceiba pentandra Linn.). Indian Journal of Forestry 17(4): 293 300.

Cheema, G. S. and Dani, P. G. (1990). In. Fruits-Tropical and Subtropical, vol.- 1. (Eds. Bose, T.K., Mitra, S.K. and Sanyal, D.), Naya Prakash. p. 507.

Dhankhar, D. S. and Singh, M. (1996). Seed germination and seedling growth in aonla (Phyllanthus emblica Linn.) as influenced by gibberellic acid and thiourea. Field Crop Research. 12(3): 363-366.

Dhinesh Babu, K., Patel, R. K., Singh, A., Yadav, D. S., De, L. C. and Deka, B. C. (2010). Seed germination, seedling growth and vigour of papaya under north East Indian condition. Acta Horticulture 851: 299-306.

Feucht, J. R. and Watson, D. P. (1958). The effect of gibberellins on internal tissues of pea (Phaseolus vulgaris L.). American Journal of Botany 45: 520522.

Heywood, VH; Brummitt, RK; Culham, A; and Seberg, O (2007). Flowering plant families of the world. Firefly Books. p. 88.

Khan, A. A. (1981). Hormonal regulation of primary and secondary seed dormancy. Israel Journal of Botany. 24: 207-224.

Morton JF (1987). "Papaya". New CROP, the New Crop Resource Online Program, Center for New Crops \& Plant Products, Purdue University; from p. 336-346.

Nelson, K., Srimathi, P. and Ponnuswamy, A. S. (2008). Influence of potting mixture on elite seedling production in arnotta plant (Bixa orellana). The Madras Agricultural Journal, 95(7-12): 496498. 
Paleg, L. (1965). Physiological effects of gibberellins. Annual Review of Plant Physiology, 16: 291-322.

Parasana, J. S., Leua, H. N. and Ray, N. R. (2014). Effect of different growing medias mixtures on germination and seedling growth of mango (Mangifera indica L.) cultivars under net house conditions. The Bioscan. 8(3): 897-900.

Pawshe, Y. H., Patil, B. N. and Patil, L. P. (1997). Effect of pregermination seed treatments on germination and vigour of seedlings in Aonla (Emblica officinalis G.). PKV Research Journal, 21: 152154.

Ramteke, V., Paithankar, D.H., Ekta P.N., and Kurrey V.K. (2015). Effect of $\mathrm{GA}_{3}$ and Propagation media on germination growth and vigour of papaya cv. Coorg Honey Dew. The Bioscan. 10(3): 10111016.

Sen, S. K., Hore, J. K. and Bandyopadhyay, A. (1990). Pre-sowing seed treatment and its role on germination, seedling growth and longevity of papaya. Orissa journal of Agricultural Research, 2(34): 160-164.
Shamet, G. S., Chauhan, P. S. and Sood, R. (1994). Nursery-studies on potting mixture, mulching and fertilizer requirements of chilgoza pine (Pinus gerardiana Wall.). Indian Journal of Forestry. 17(3): 225-229.

Wagh, A. P., Choudhary, M. H., Kulwal, L. V., Jadhav, B. J. and Joshi, P. S. (1998). Effect of seed treatment on germination of seed and initial growth of aonla seedling in polybags. $P K V$ Research Journal, 22(2): 176-177.

Wilson S.B., Stoffella P.J., and Graetz D.A. (2011). Use of compost as a media amendment for containerized production of two subtropical perennials. Journal Environmental Horticulture. 19: 37 - 42.

Yadav, R. K., Jain, M. C. and Jhakar, R. P. (2012). Effect of media on growth and development of acid lime (Citrus aurantifolia Swingle) seedling with or withour Azotobacter. African Journal of Agricultural Research, 7(48):64216426.

\section{How to cite this article:}

Unmesh Mishra, Vijay Bahadur, V.M. Prasad, Pushpendra Verty, Ashutosh Kumar Singh, Saket Mishra and Swaroop N. 2017. Influence of GA3 and Growing Media on Growth and Seedling Establishment of Papaya (Carica papaya L.) cv. Pusa Nanha. Int.J.Curr.Microbiol.App.Sci. 6(11): 415-422. doi: https://doi.org/10.20546/ijcmas.2017.611.048 